\title{
HUBUNGAN KANDUNGAN N- TOTAL DAN C-ORGANIK TANAH TERHADAP BERAT PANEN TANAMAN PAKCOY PADA KOMBINASI KOMPOS SAMPAH KOTA DAN PUPUK KANDANG SAPI
}

\author{
Henly Yulina ${ }^{1 *}$ dan Wiwik Ambarsari ${ }^{2}$ \\ ${ }^{1}$ Fakultas Pertanian, Universitas Bale Bandung \\ ${ }^{2}$ Fakultas Pertanian, Universitas Wiralodra, Indramayu \\ *henlyyulina2089@gmail.com
}

\begin{abstract}
The objective of this research was to find out relationship between N- Total content and C- Organic soil to the harvest weight of pakcoy after combined with municipal waste compost and cow manure in Alluvial, Indramayu. This study used a randomized block design factorial with two factors. The first factor is municipal waste compost and the second factor is cow manure. Each of them consisted of 4 levels : $0 \%, 3.0 \%, 6.0 \%$, and $9.0 \%$ with two replication, followed by regression analysis and linear correlation. The results showed that there was a relationship between $\mathrm{N}$ - Total content and C- Organic soil with harvest weight of pakcoy. The harvest weight of pakcoy was influenced by $\mathrm{N}$ - Total content and $\mathrm{C}$ Organik soil, so that the N- Total and C-Organic soil can increase the harvest weight of pakcoy.
\end{abstract}

Keywords: municipal waste compost, cow manure, NTotal content, C-Organik soil, pakcoy

\begin{abstract}
ABSTRAK
Penelitian bertujuan untuk mengetahui hubungan kandungan N- Total dan C- Organik tanah terhadap berat panen tanaman pakcoy setelah dikombinasikan dengan kompos sampah kota dan pupuk kandang sapi pada Aluvial, Indramayu. Penelitian ini menggunakan Rancangan Acak Kelompok Pola Faktorial dengan dua faktor. Faktor pertama kompos sampah kota dan faktor kedua pupuk kandang sapi masing- masing 4 taraf : $0 \%$, $3,0 \%, 6,0 \%$, dan $9,0 \%$, diulang dua kali dilanjutkan dengan analisis regresi dan korelasi linier. Hasil penelitian menunjukkan bahwa terdapat terdapat hubungan antara N- Total dan C- Organik tanah dengan berat panen tanaman pakcoy. Berat panen tanaman pakcoy dipengaruhi oleh N- Total dan C- Organik, sehingga kandungan $\mathrm{N}$ - total dan $\mathrm{C}$ - Organik tanah dapat meningkatkan berat panen tanaman pakcoy.
\end{abstract}

Kata kunci : kompos sampah kota, pupuk kandang sapi, N- Total, C- Organik tanah, pakcoy

\section{PENDAHULUAN}

Aluvial atau tanah endapan merupakan salah satu jenis tanah kritis yang banyak terdapat di dataran rendah, di muara sungai, rawa-rawa, lembah-lembah, maupun kanan kiri aliran sungai termasuk di Kabupaten Indramayu. Profilnya biasanya belum jelas, pada umumnya banyak mengandung pasir dan tidak banyak mengandung unsur-unsur hara, dan kesuburannya sedang hingga tinggi. Namun tanah ini merupakan tanah pertanian yang baik dan dimanfaatkan untuk tanaman pangan musiman hingga tahunan (Rismunandar, 1993). Upaya meningkatkan kandungan unsur- unsur hara di dalam tanah tersebut adalah dengan memberikan bahan pembenah tanah seperti pupuk organik.

Pupuk organik yang digunakan pada penelitian ini, yaitu kompos sampah kota dan pupuk kandang sapi. Kompos sampah kota dan pupuk kandang sapi sangat banyak dan mudah didapatkan di Kabupaten Indramayu. Hasil dekomposisi kotoran sapi akan melepaskan sejumlah senyawa karbon (C) sebagai penyusun utama dari bahan organik itu sendiri, yang akan menambah kadar C- Organik pada tanah (Fikdalillah, et.,al., 2016). Bahan organik yang tinggi berkorelasi terhadap kandungan C-organik.

Kandungan $\mathrm{N}$ total dan kadar fosfor kompos sampah kota termasuk tinggi yaitu $2,71 \% \mathrm{~N}$ dan $2,53 \%$. $\mathrm{P}_{2} \mathrm{O}_{5}$. Begitu juga dengan kandungan $\mathrm{N}$ total dan kadar fosfor pupuk kandang sapi yaitu $3,26 \% \mathrm{~N}$ dan $3,42 \% \mathrm{P}_{2} \mathrm{O}_{5}$. Hal ini disebabkan oleh asam- asam organik hasil dekomposisi bahan organik sangat efektif dalam membebaskan $P$ yang terfiksasi oleh $\mathrm{Al}$ dan $\mathrm{Fe}$ dalam larutan tanah, sehingga $\mathrm{P}$ lebih tersedia bagi tanaman (Sari, M., et., al., 2017), sehingga bermanfaat untuk meningkatkan pertumbuhan tanaman.

Tanaman yang digunakan pada penelitian ini adalah pakcoy. Pakcoy merupakan tanaman sayur daun yang memiliki nilai ekonomis tinggi. Pertumbuhan pada tanaman pakcoy lebih didominasi oleh pertumbuhan vegetatif, sehingga membutuhkan unsur hara yang cukup untuk pembentukan bagian tanaman pada pakcoy. Peningkatan produksi tanaman pakcoy dapat dilakukan melalui pemupukan dengan pupuk organik (Shinta, et., al., 2017). Unsur hara C dan N 
merupakan salah satu unsur hara makro yang dibutuhkan untuk meningkatkan pertumbuhan tanaman, sehingga akan meningkatkan produktivitas tanaman pakcoy.

\section{BAHAN DAN METODE}

Penelitian ini dilakukan di Kebun Percobaan Fakultas Pertanian, Universitas Wiralodra Kabupaten Indramayu dari bulan Januari sampai Desember 2018. Penelitian ini menggunakan Rancangan Acak Kelompok (RAK) pola faktorial dengan dua faktor. Faktor pertama adalah kompos sampah kota dan faktor kedua adalah pupuk kandang sapi, masing - masing terdiri dari empat taraf, yaitu $0 \%, 3,0 \%, 6,0 \%$ dan $9,0 \%$ yang di ulang sebanyak dua kali. Total kombinasi perlakuan $4 \times 4 \times 2=32$ pot percobaan. Kompos sampah kota diperoleh dari TPA Pecuk Kabupaten Indramayu dan pupuk kandang sapi dari Peternakan Sapi Kelompok Tunggal Rasa di Desa Majasari Kecamatan Sliyeg Kabupaten Indramayu. Kombinasi perlakuan dapat dilihat pada Tabel 1.

Tabel 1. Kombinasi Perlakuan Kompos Sampah Kota dan Pupuk Kandang Sapi

\begin{tabular}{ccccc}
\hline Kompos Sampah Kota & \multicolumn{3}{c}{ Pupuk kandang sapi (K) } \\
\cline { 2 - 5 }$(\mathrm{S})$ & $\mathrm{k}_{1}$ & $\mathrm{k}_{2}$ & $\mathrm{k}_{3}$ & $\mathrm{k}_{4}$ \\
\hline $\mathrm{s}_{1}$ & $\mathrm{~s}_{1} \mathrm{k}_{1}$ & $\mathrm{~s}_{1} \mathrm{k}_{2}$ & $\mathrm{~s}_{1} \mathrm{k}_{3}$ & $\mathrm{~s}_{1} \mathrm{k}_{4}$ \\
$\mathrm{~s}_{2}$ & $\mathrm{~s}_{2} \mathrm{k}_{1}$ & $\mathrm{~s}_{2} \mathrm{k}_{2}$ & $\mathrm{~s}_{2} \mathrm{k}_{3}$ & $\mathrm{~s}_{2} \mathrm{k}_{4}$ \\
$\mathrm{~s}_{3}$ & $\mathrm{~s}_{3} \mathrm{k}_{1}$ & $\mathrm{~s}_{3} \mathrm{k}_{2}$ & $\mathrm{~s}_{3} \mathrm{k}_{3}$ & $\mathrm{~s}_{3} \mathrm{k}_{4}$ \\
$\mathrm{~s}_{4}$ & $\mathrm{~s}_{4} \mathrm{k}_{1}$ & $\mathrm{~s}_{4} \mathrm{k}_{2}$ & $\mathrm{~s}_{4} \mathrm{k}_{3}$ & $\mathrm{~s}_{4} \mathrm{k}_{4}$ \\
\hline
\end{tabular}

Pengamatan utama yang di analisis secara statistik adalah kandungan N-Total, C-Organik dan Berat Panen Tanaman Pakcoy setelah media tanam dikombinasikan dengan kompos sampah kota dan pupuk kandang sapi. Setelah hasil analisisnya diperoleh dilanjutkan dengan menguji hubungan masing-masing perlakuan dengan model regresi linier sederhana.

$$
\begin{aligned}
& \mathrm{Y}=\beta_{0}+\beta_{1} \mathrm{X}+\varepsilon \\
& \hat{\mathrm{Y}}=\mathrm{a}+\mathrm{bX}
\end{aligned}
$$

dimana

$\hat{\mathrm{Y}}=$ peubah tak bebas (berat panen tanaman pakcoy )

$\mathrm{X}=$ peubah bebas $(\mathrm{N}-$ Total dan $\mathrm{C}$ Organik)

$\mathrm{a}=$ koefisien intercept

$\mathrm{b}=$ koefisien regresi

Berdasarkan model linier di atas, maka disusun analisis regresi linier sederhana yang dapat dilihat pada Tabel 2 sebagai berikut:

\begin{tabular}{|c|c|c|c|c|c|}
\hline Sumber Keragaman & $\mathrm{DB}$ & $\mathrm{JK}$ & KT & F hitung & $\mathrm{F}_{0,05}$ \\
\hline $\mathrm{R}(\mathrm{b} / \mathrm{a})$ & 1 & JK R & KT R & KT R/KTG & \\
\hline Galat $(\varepsilon)$ & $n-2$ & $\mathrm{JKG}$ & KTG & - & \\
\hline Total & $\mathrm{n}-1$ & & & & \\
\hline
\end{tabular}

Tabel 2. Analisis Regresi Linier Sederhana

Sumber : Gasperz (1991).

Tanah yang digunakan berasal dari lahan pekarangan Desa Majasari Kecamatan Sliyeg Kabupaten Indramayu yang diambil pada kedalaman $20 \mathrm{~cm}$ secara komposit. Tanah kemudian dicampurkan dengan perlakuan dan dimasukkan kedalam 32 polybag (ukuran $50 \mathrm{~cm} \mathrm{x}$ $35 \mathrm{~cm}$ ). Inkubasi dilakukan selama 4 minggu. Selama inkubasi berlangsung, secara berkala (1 minggu 2 kali) dilakukan pembalikan dan penimbangan berat tanah untuk mengetahui apakah terjadi penurunan berat tanah. Jika terjadi penurunan berat tanah selama inkubasi maka dilakukan pemberian air hingga mencapai berat tanah awal (kapasitas lapang).
Pakcoy dapat dipanen pada umur 30-35 hari setelah tanam (Wahyudi, 2010). Pupuk yang digunakan adalah $187 \mathrm{~kg}$ ha-1 Urea, $311 \mathrm{~kg} \mathrm{ha}^{-1}$ SP-36 dan $112 \mathrm{~kg}$ ha- ${ }^{1} \mathrm{KCl}$ sebelum tanam dan 187 kg ha-1 Urea serta $112 \mathrm{~kg}$ ha- ${ }^{1} \mathrm{KCl}$ setelah 3 minngu tanam (Susila Anas, 2006) dengan jarak tanam $20 \mathrm{~cm}$ x $20 \mathrm{~cm}$ (Barokah, et., al., 2012). Pakcoy dapat dipanen ketika daunnya telah lebar dan batangnya lebih berwarna putih. Panen dilakukan dengan cara memotong pangkal batang menggunakan pisau tajam.

Sampel tanaman di ambil setelah tanaman pakcoy mencapai fase vegetatif, tanaman ditimbang secara keseluruhan dari pupus akar 
sampai dengan daun untuk mengetahui berat panen tanaman pakcoy. Analisis dilakukan di

\section{HASIL DAN PEMBAHASAN}

Hasil uji di Laboratorium Kesuburan Tanah dan Nutrisi Tanaman, Departemen Ilmu Tanah dan Sumberdaya Lahan, Fakultas Pertanian, Universitas Padjadjaran menyatakan bahwa kandungan kompos sampah kota untuk kandungan N- Total dan C-

Hasil analisis statistik menunjukkan bahwa tidak terjadi interaksi antara kompos sampah kota dengan pupuk kandang sapi terhadap kandungan $\mathrm{N}$-Total tanah pada tanaman pakcoy setelah panen.
Laboratorium Fakultas Pertanian, Universitas Wiralodra.

Tabel 3. Pengaruh Mandiri Pupuk Kandang Sapi terhadap N- Total Tanah pada Tanaman Pakcoy setelah Panen

\begin{tabular}{lc}
\multicolumn{1}{c}{ Perlakuan } & N-Total \\
Pupuk Kandang Sapi $(\mathrm{K})$ & $(\%)$ \\
\hline $\mathrm{K}_{1}$ (Tanpa pupuk kandang sapi /kontrol) & $0,20 \mathrm{a}$ \\
$\mathrm{K}_{2}(3,0 \%$ pupuk kandang sapi terhadap media tanam) & $0,22 \mathrm{ab}$ \\
$\mathrm{K}_{3}(6,0 \%$ pupuk kandang sapi terhadap media tanam) & $0,24 \mathrm{bc}$ \\
$\mathrm{K}_{4}(9,0 \%$ pupuk kandang sapi terhadap media tanam) & $0,25 \mathrm{c}$ \\
\hline
\end{tabular}

Keterangan: Angka yang diikuti oleh huruf yang sama, tidak berbeda nyata menurut Uji Jarak Berganda Duncan pada taraf $5 \%$.

Data pada Tabel 3 menunjukkan bahwa pemberian pupuk kandang sapi meningkatkan kandungan $\mathrm{N}$ - Total tanah pada tanaman pakcoy setelah panen. Peningkatan terbesar terjadi pada dosis $9,0 \%\left(\mathrm{k}_{4}\right)$, namun pada dosis $3,0 \%\left(\mathrm{k}_{2}\right)$ pupuk kandang sapi, kandungan N-Total sudah meningkat.

Tabel 4. Pengaruh Mandiri Pupuk Kandang Sapi terhadap C- Organik Tanah pada Tanaman Pakcoy setelah Panen

\begin{tabular}{lc}
\multicolumn{1}{c}{ Perlakuan } & C-Organik \\
Pupuk Kandang Sapi $(\mathrm{K})$ & $(\%)$ \\
\hline $\mathrm{K}_{1}$ (Tanpa pupuk kandang sapi /kontrol) & $2,04 \mathrm{a}$ \\
$\mathrm{K}_{2}(3,0 \%$ pupuk kandang sapi terhadap media tanam) & $2,21 \mathrm{ab}$ \\
$\mathrm{K}_{3}(6,0 \%$ pupuk kandang sapi terhadap media tanam) & $2,43 \mathrm{bc}$ \\
$\mathrm{K}_{4}(9,0 \%$ pupuk kandang sapi terhadap media tanam) & $2,53 \mathrm{c}$ \\
\hline
\end{tabular}

Keterangan: Angka yang diikuti oleh huruf yang sama, tidak berbeda nyata menurut Uji Jarak Berganda Duncan pada taraf $5 \%$

Hasil analisis statistik menunjukkan bahwa tidak terjadi interaksi antara kompos sampah kota dengan pupuk kandang sapi terhadap kandungan COrganik tanah pada tanaman pakcoy setelah panen. Hasil analisis statistik menunjukkan bahwa pupuk kandang sapi berpengaruh mandiri terhadap kandungan C- Organik tanah pada tanaman pakcoy setelah panen (Tabel 4).

\section{Hubungan N- Total Tanah dengan Berat Panen Tanaman Pakcoy \\ Nitrogen mempunyai peran penting dalam} merangsang pertumbuhan tanaman secara keseluruhan, khususnya batang, cabang, dan daun. Selain itu, nitrogen pun berperan penting dalam
Data pada tabel 4 menunjukkan bahwa penambahan pupuk kandang sapi dapat meningkatkan kandungan C- Organik tanah pada tanaman pakcoy setelah panen. Peningkatan terbesar terjadi pada dosis $9,0 \%\left(\mathrm{k}_{4}\right)$ yang berbeda nyata dengan kontrol dan perlakuan $\mathrm{k}_{2}$, namun tidak berbeda nyata dengan perlakuan $\mathrm{k}_{3}$.

pembentukan zat hijau daun yang sangat berguna dalam proses fotosintesis, sehingga dapat berpengaruh terhadap berat segar tanaman pakcoy. Hal ini dapat dilihat pada Gambar 1 di bawah ini. 


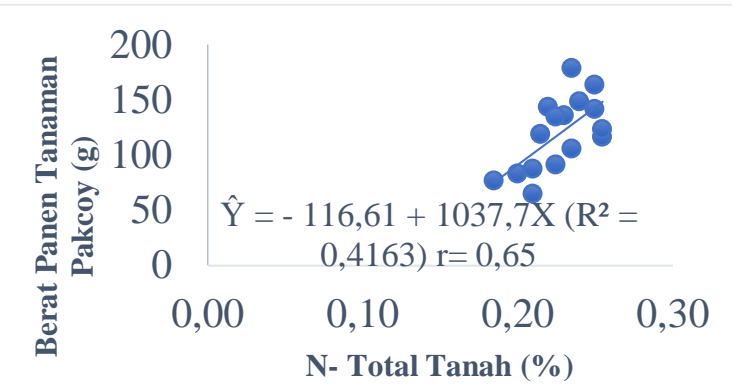

Gambar 1. Hubungan N- Total Tanah dengan Bera Panen Tanaman Pakcoy
Data pada Gambar 1 menunjukkan bahwa $\mathrm{N}$ - Total tanah (X) mempunyai hubungan dengan berat panen tanaman pakcoy (Y), semakin besar NTotal tanah bagi tanaman maka berat panen tanaman pakcoy semakin besar $(\mathrm{r}=0,65)$. Berdasarkan persamaan regresi linier $\hat{Y}=-116,61$ $+1037,7 \mathrm{X}\left(\mathrm{R}^{2}=0,4163\right)$, berat panen tanaman pakcoy dipengaruhi oleh $\mathrm{N}$ - Total tanah sebesar $65 \%$. Faktor-faktor lain memberikan pengaruh sebesar $35 \%$ terhadap berat panen tanaman pakcoy.

Berdasarkan data pada gambar hubungan $\mathrm{N}$ Total tanah dengan berat panen tanaman pakcoy di atas, maka disusun persamaan regresi yang dapat dilihat pada Tabel 3 di bawah ini :

Tabel 3. Daftar Persamaan Regresi Hubungan Berat Panen Tanaman Pakcoy dengan N- Total Tanah.

\begin{tabular}{cccc}
\hline Tanaman & Persamaan Regresi & $\mathrm{R}^{2}$ & $\mathrm{r}$ \\
\hline Pakcoy & $\hat{\mathrm{Y}}=-116,61+1037,7 \mathrm{X}$ & 0,4163 & $0,65^{*}$ \\
\hline Keterangan $:{ }^{*)}$ berbeda nyata \\
tn) \\
tidak berbeda nyata
\end{tabular}

Data pada Tabel 3 menunjukkan bahwa berat panen tanaman pakcoy dipengaruhi oleh $\mathrm{N}$ Total tanah. Fungsi Nitrogen untuk tanaman sayuran yaitu sebagai penyusun protein, pertumbuhan pucuk tanaman dan menyuburkan pertumbuhan vegetatif, sehingga sesuai untuk tanaman sayuran daun seperti sawi (Kholidin, et., al., 2016) .Sumber nitrogen di alam tersedia sangat melimpah di udara namun tidak bisa secara langsung digunakan oleh tanaman. Berdasarkan jenisnya nitrogen dapat berasal dari bahan organik maupun anorganik. Bahan organik yaitu dari dekomposisi mahluk hidup yang mati sedangkan yang anorganik dapat dari udara maupun hujan. Berdasarkan dari asalnya nitrogen dapat berasal secara alami yaitu dari udara dan bantuan dari bakteri.

Hubungan C-Organik Tanah dengan Berat Panen Tanaman Pakcoy

C- Organik (Bahan Organik) merupakan presentase kesuburan tanah, yang mempunyai banyak manfaat bagi tanaman salah satunya sebagai sumber hara bagi tanaman, sehingga akan meningkatkan produktivitas tanaman. Hal ini dapat dilihat pada Gambar 2 di bawah ini.

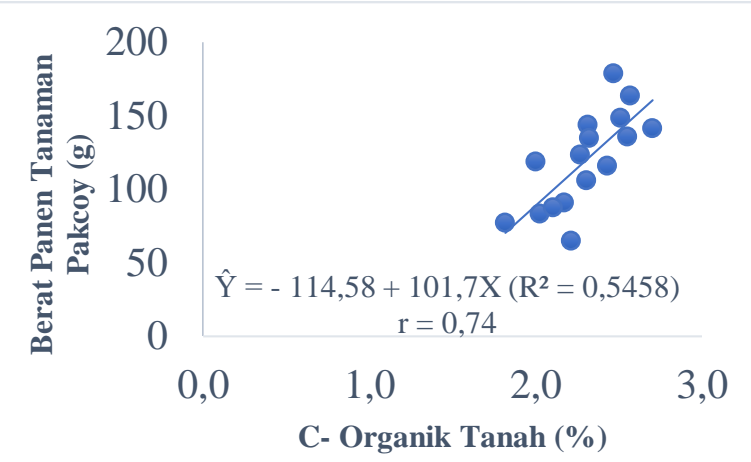

Gambar 2. Hubungan C- Organik Tanah dengan Berat Panen Tanaman Pakcoy

Data pada Gambar 2 menunjukkan bahwa C- Organik tanah (X) mempunyai hubungan dengan berat panen tanaman pakcoy (Y), semakin tinggi $\mathrm{C}$ - Organik tanah bagi tanaman maka berat panen tanaman pakcoy semakin besar $(r=0,74)$. Berdasarkan persamaan regresi linier $\hat{\mathrm{Y}}=-114,58$ $+101,7 \mathrm{X}\left(\mathrm{R}^{2}=0,5458\right)$, berat panen tanaman pakcoy dipengaruhi oleh C-Organik tanah sebesar 74\%. Faktor-faktor lain memberikan pengaruh sebesar $26 \%$ terhadap berat panen tanaman pakcoy.

Berdasarkan data pada gambar hubungan COrganik tanah dengan berat panen tanaman pakcoy di atas, maka disusun persamaan regresi yang dapat dilihat pada Tabel 4 di bawah ini :

Tabel 4. Daftar Persamaan Regresi Hubungan Berat Panen Tanaman Pakcoy dengan C- Organik Tanah.

\begin{tabular}{cccc}
\hline Tanaman & Persamaan Regresi & $\mathrm{R}^{2}$ & $\mathrm{r}$ \\
\hline Pakcoy & $\hat{\mathrm{Y}}=-114,58+101,7 \mathrm{X}$ & 0,5458 & $\left.0,74^{*}\right)$ \\
\hline Keterangan : ${ }^{*}$ berbeda nyata & & & \\
& &
\end{tabular}


Data pada Tabel 4 menunjukkan bahwa berat panen tanaman pakcoy dipengaruhi oleh $\mathrm{C}$ Organik tanah.

Bahan organik memiliki peran penting dalam pertimbuhan dan produktivitas tanaman pakcoy. Bahan organik berperan sebagai pembentuk butir mineral yang menyebabkan terjadinya keadaan gembur pada tanah (Khairunnas dan Tety, 2011), selain itu bahan organik meningkatkan daya menahan air (water holding capacity) sehingga kemampuan tanah untuk menyediakan air bagi tanaman menjadi lebih banyak, kelengasan air tanah lebih terjaga (Rosmarkam dan Yuwono, 2002).

Bahan organik yang tinggi berkorelasi terhadap kandungan C-organik. Kandungan Corganik termasuk sangat tinggi, yaitu 41,94. Tingginya C-organik dapat mempertahankan kualitas fisika tanah untuk membantu perkembangan akar tanaman dan kelancaran pergerakan air tanah melalui pembentukan pori tanah dan kemantapan agregat tanah (Hairiah, 2000).

Bahan organik dapat memperbaiki struktur tanah, meningkatkan kapasitas menahan air, pori aerasi, dan laju infiltrasi, serta memudahkan penetrasi akar, sehingga produktivitas lahan dan hasil tanaman dapat meningkat (Suwardjo et al. 1996).

Pemberian bahan organik tidak hanya menghasilkan kondisi fisik tanah yang baik, tetapi juga menyediakan bahan organik hasil pelapukan yang dapat menambah unsur hara bagi tanaman, meningkatkan $\mathrm{pH}$ tanah dan kapasitas tukar kation, menurunkan Aldd, serta meningkatkan aktivitas biologi tanah (Subowo, et., al., 1990, Sukristiyonubowo, et., al., 1993).

Pada penelitian ini penggunaan bahan organik berupa pupuk sampah kota dan pupuk kandang sapi dapat meningkatkan pertumbuhan dan berat panen tanaman pakcoy.

\section{KESIMPULAN}

Terdapat hubungan antara N- Total dan COrganik tanah dengan berat panen tanaman pakcoy. Berat panen tanaman pakcoy dipengaruhi oleh $\mathrm{N}$ Total dan C- Organik, sehingga kandungan N- total dan C- Organik Tanah dapat meningkatkan berat panen tanaman pakcoy.

\section{UCAPAN TERIMA KASIH}

Saya mengucapkan terima kasih kepada Kemenristek DIKTI yang sudah memberikan hibah untuk Penelitian Dosen Pemula, sehingga dapat menyelesaikan penelitian ini. Saya mengucapkan terima kasih juga kepada Bapak Dekan Fakultas Pertanian karena telah mengizinkan Kebun Percobaan Fakultas Pertanian, Universitas Wiralodra digunakan untuk penelitian kami.

\section{DAFTAR PUSTAKA}

Barokah, U., Suprapti, dan Sugiharti. (2012). Dampak Konversi Lahan Pertanian Terhadap Pendapatan Rumah Tangga Petani di Kabupaten Karanganyar. Jurnal Caraka Tani. Vol XXVII (1): 93-99.

Fikdalillah, M. Basir, dan I. Wahyudi. (2016). Pengaruh Pemberian Pupuk Kandang Sapi terhadap Serapan Fosfor dan Hasil Tanaman Sawi Putih (Brassica pekinensis) pada Entisol Sidera. Jurnal Agrotekbis. 4 (5) : 491-499. ISSN : 2338-3011.

Gaspersz, V. (1991). Metode Perancangan

Percobaan. CV. Armico, Bandung.

Hairiah, K. (2000). Pengelolaan Tanah Masam secara Biologi. International Centre for Research In Agroforestry, Bogor.

Khairunnas, dan Tety, E. (2011). Analisis Kelayakan Usahatani Buah Naga (Hylocereus costaricensis) di Pekanbaru. Jurnal pekbis, 3 : 579-585

Kholidin, A. R., H. N. Barus. (2016). Respon pertumbuhan dan hasil tanaman sawi (Brassica juncea l.) terhadap kombinasi pupuk organik, anorganik dan mulsa di lembah palu. Jurnal Agrotekbis Vol.4 (1):17.

Rismunandar. (1993). Кауи Manis. Penebar Swadaya, Jakarta.

Rosmarkam, A.W., dan Yuwono. (2002). Ilmu Kesuburan Tanah. Kanisius. Yogyakarta. Hal. 214.

Sari, M.N., Sudarsono, dan Darmawan. 2017. Pengaruh Bahan Organik Terhadap Ketersediaan Fosfor pada Tanah-Tanah Kaya Al dan Fe. Buletin Tanah dan Lahan. 1.(1). 65-71.

Shinta, Didik. H, dan Moch. D. Maghfoer. (2017). Penggunaan Kompos Sampah Kota dan Pupuk Urea terhadap Pertumbuhan dan Hasil Tanaman Pakcoy (Brassica rapa L.). Jurnal Produksi Tanaman. 5 (8). ISSN : 2527-8452.

Subowo, J., Subaga dan Sudjadi M. (1990). Pengaruh Bahan Organik terhadap Pencucian Hara Tanah Ultisol Rangkasibitung, Jawa Barat. Pemberitaan Penelitian Tanah dan Pupuk. 9: 26-31.

Sukristiyonubowo, Mulyadi, P. Wigena, dan A. Kasno. (1993). Pengaruh Penambahan Bahan Organik,Kapur, dan Pupuk NPK 
terhadap Sifat Kimia Tanah dan Hasil Kacang Tanah. Pemberitaan Penel Tanah dan Pupuk Vol. 11, pp.1-6.

Susila, Anas. (2006). Panduan Budidaya Tanaman Sayuran. Departemen Agronomi dan Holltikultura. Fakultas Pertanian. IPB, Bogor.

Suwardjo, H., Sunyoto, Rb., Wahyunto, dan Dariah, A. (1996). Penyebaran lahan kritis dan teknologi penanggulangannya di Kawasan Timur Indonesia. Prosiding Temu Konsultasi Sumberdaya Lahan untuk Pembangunan Kawasan Timur Indonesia. Palu, 17-20 Januari 1994. Bogor: Puslittanak. Hal. 275-295.

Wahyudi. (2010). Petunjuk Praktis Bertanam Sayuran. Agromedia Pustaka, Jakarta. 